\title{
Blanket Toss Under Midnight Sun: Portraits of Everyday Life in Eight Indigenous Communities
}

Paul Seesequasis. Alfred A. Knopf, Toronto, 2019. 192 pages, with 47 colour and 27 black \& white illustrations. Softcover $£ 20.15 / \$ 32.95$, ISBN 978-0-735-27331-3.

\section{Mark Turin}

To cite this article: Mark Turin (2020): Blanket Toss Under Midnight Sun: Portraits of Everyday Life in Eight Indigenous Communities, History of Photography, DOI: 10.1080/03087298.2020.1846335

To link to this article: https://doi.org/10.1080/03087298.2020.1846335

$$
\text { 曲 Published online: } 30 \text { Nov } 2020 .
$$

Submit your article to this journal $\sqsubset$

\section{Q View related articles $\sqsubset$}

View Crossmark data $־$ 


\section{Book Review}

\section{Blanket Toss Under Midnight Sun: Portraits of Everyday Life in Eight Indigenous Communities}

Paul Seesequasis. Alfred A. Knopf, Toronto, 2019. 192 pages, with 47 colour and 27 black \& white illustrations. Softcover $£ 20.15 / \$ 32.95$, ISBN 978-0-735-27331-3.

This beautiful book is an impressive byproduct of a much larger digital research project that speaks to the resilience and cultural strength of Indigenous communities in what are now Canada and the USA. Its creator is Paul Seesequasis, a nîpisîhkopâwiyiniw (Willow Cree) writer, journalist, cultural advocate and commentator based in Saskatoon, Saskatchewan, whose mother is a survivor of the Canadian residential school system.

Canadian residential schools were government-sponsored religious institutions established to assimilate Indigenous (previously referred to as Indian, Native and Aboriginal) children into dominant Euro-Canadian culture. Even though Indian residential schools in Canada, American Indian boarding schools in the USA, native schools for Māori in New Zealand and Christian missionary schools in Hawai were governed and shaped by diverse motivations, they were united by a prejudiced belief that Indigenous cultures were backward, primitive and incompatible with modernity and Western values.

Active in Canada from the mid 1800s to the late 1990s, these racist and demeaning establishments have caused profound disruption to the livelihoods and lasting damage to the lives of Indigenous communities. Moreover, they offered little educational value to those who were forced to attend. Through brutal and punitive mechanisms that intentionally devalued Indigenous languages, cultures and traditional practices, the state sought to weaken family ties in Indigenous communities and assimilate or exterminate the Indigenous populations of this recently settled land.

In 2015, the Truth \& Reconciliation Commission of Canada released its report detailing the history of Indigenous peoples' lived experiences through the residential school system. The Commission heard and documented over six thousand testimonies from survivors and their families. When Seesequasis found himself grappling with the Commission's devastating findings and coming to terms with this violent period in Canada's colonial history, his mother told him that she was 'tired of hearing just negative things about those times', reminding him that there had also been 'positive and strong things in Indigenous communities then'.

Galvanised by her words, Seesequasis began to search through archives, libraries, museums and private collections for images of Indigenous life that reflected integrity, strength, resourcefulness, hard work, family and play' rather than suffering and exploitation. Blanket Toss Under Midnight Sun is tangible proof that he found what he was looking for. His exploration would soon mature into a multiyear, collaborative social media project through which Seesequasis collected archival photographs of everyday life in First Nations, Métis and Inuit communities from across Canada from the 1920s to the 1970s, and harnessed the connective and communicative power of the Internet to 'assemble, digitize and distribute' them. Three years and hundreds of photographs later, Seesequasis still feels that he is just 'scratching the surface' and that this uncovering and retelling process holds much potential. In a 2019 interview, Seesequasis describes his work as more of a marathon than a sprint: 'It's not the type of book you can rush. Everyone had to have a sense of patience and just go with the flow' (Maclean's, 19 October 2019).

Organised by geographic and administrative region, Blanket Toss under Midnight Sun is representative rather than comprehensive or encyclopaedic. First-person narratives and poignant, historical vignettes contextualise the images that make up the eight chapters of the book. A humbly-worded 'Introduction' and a forward-looking 'Epilogue' bookend the collection, through which we learn how aware Seesequasis is of the seductive historical logic of the visual records that he has helped to unearth. Just as he approaches the 'narratives that make up this book as stories inspired by the photographs, not ultimate truths', Seesequasis observes that not all of the accompanying archival notes that he identified in his research were 'accurate in name, location or cultural identity'. By exposing the vulnerabilities of historical reconstruction and memory, and being transparent about his methodology, Seesequasis offers readers a practical handbook on effective engagement with compromised colonial archives: 'Never add your assumptions to the captions. Reprint the archival captions as they are, but expect, in many cases, they will be wrong or inaccurate'.

Seesequasis weaves language, culture and history into the text panels that accompany the images in ways that are skilful and effortless. We learn, for example, that in the northern Quebec territory of Nunavik, government-sponsored dog slaughters - the goal of which was to sever Indigenous peoples from their traditional territories and diets - resulted in the needless and wanton destruction of more than twenty thousand active sled dogs in the course of just two decades. On a more uplifting note, in the text accompanying a 1973 photograph of the Fort George Rockers, an Indigenous band, the reader is treated to a description of what was 'probably the first-ever rock tour by canoe, visiting three James 
Bay communities'. Seesequasis's masterful pairing of image with text help animate the story of the first generation of Indigenous photographers, visionaries such as Peter Pitseolak and George Johnston, who led the way in turning their 'lenses outward with their gaze on the dominant societal structures'.

Reading this book - and reviewing Seesequasis's tremendous mobilisation on Twitter and his sustained engagement with more than sixteen thousand followers who regularly respond, amplify and share his posts - I returned to Audre Lorde's timely statement that 'the master's tools will never dismantle the master's house. They may allow us temporarily to beat him at his own game, but they will never enable us to bring about genuine change' (Sister Outsider: Essays and Speeches 1984). We know that the digital return of visual records of marginalised and colonised communities cannot redress the wrongs of the past, and neither does such a process necessarily result in a more equitable present. Yet, by harnessing the power of publishing and social media to connect photographic subjects and their descendants with their own visual record, Seesequasis is advancing a decolonial agenda - in both image and text - that is both highly relevant and extremely effective. As he writes, 'the story is only a small part of the picture and the picture is only a small part of the story'.

Blanket Toss under Midnight Sun is a profoundly humane and optimistic book, and, at the same time, serves as a gentle act of resistance and reclamation. In reasserting representational sovereignty, Seesequasis is resetting history, centring specific Indigenous individuals - not imagined cultural collectives or anthropological others - at the heart of this visually gripping story. Integrating collaborative, community-based research, instruction, curation, publishing and outreach in ways that have long been practised by Indigenous communities the world over, and are now the aspirational standard of almost all neoliberal universities, Seesequasis achieves something exceptional. He humanises our shared past, invites us into the present and outlines a path on which we may walk together to create a less racist and more respectful future.

\section{ORCID}

Mark Turin (D) http://orcid.org/0000-0002-2262-0986

Mark Turin

(C) 2020 Mark Turin

https://doi.org/10.1080/03087298.2020.1846335

Check for updates 